\title{
ROLE OF REGULATORY REFORMS FOR DEVELOPMENT AND QUALITY IMPROVEMENT OF THE CONSTRUCTION SECTOR IN MONTENEGRO
}

\author{
Mijat Jocović \\ Faculty of Economics, University of Montenegro, Podgorica, Montenegro \\ Nikola Milović \\ Faculty of Economics, University of Montenegro, Podgorica, Montenegro \\ Boban Melović \\ Faculty of Economics, University of Montenegro, Podgorica, Montenegro
}

The authors of this paper researched the influence of the quality of the regulatory rules on the construction sector in Montenegro. The authors noticed and clearly pointed out that the significance of construction for, the total economy of Montenegro, its influence on other economic activities and participance in the social gross product of the country entirely justifies the need for constant attention of the politics creators. Key issues in the legal framework which negatively influenced the improvement of competitiveness of this sector and national economy are noticed and clearly pointed out in this paper. As the most significant, the following ones are identified: trend of provisions instability, existence of mutual collision of laws and sublegal acts, regulation of spatial planning, issuing building permits, property registration and system of public procurement. After having analyzed the changes in the regulatory frame and their affect on improving the position of Montenegro on the lists of competitiveness in international organizations, the authors make a general conclusion that necessity of regulatory reform with providing a predictable and functional system is one of the basic preconditions for further development of this sector.

Key words: construction, Montenegro, economics, regulatory changes, high quality, building permits, property registration

\section{INTRODUCTION}

In the period after gaining independence, together with speeding up the economic growth, construction becomes one of the main economic activities in Montenegro. Since 2006 up to today, the construction sector approximately participates with $5 \%$ in the Gross Domestic Product (hereinafter GDP), and the intention of the creators of the economic policy is that this sector produces around $10 \%$ of the GDP of Montenegro and be one of the most dynamic economy sectors. [24] Before the global financial and economic crisis, Montenegro was characterized by increased growth which was mainly based upon high inflow of foreign direct investments. The average BDP growth rate in the period between 2006 and 2008 was $8.7 \%$. In the period between 2006 and 2011 , a growth was recorded in all economic ac- tivities, primarily in the sectors of services and construction. Investments in construction in that period made $10 \%$ of total realized investments in Montenegro. [23] On the other hand, consequences of the economic crisis negatively influenced the construction sector. We could identify numerous problems in the legal frame in this period and as a consequence they had discontent of economic subjects in this sector, but also a fall of Montenegro on the lists of competitiveness which are published by renowned international organizations. Nowadays, the state is making various efforts to find incentive mechanisms for improving the competitiveness of this industrial branch. [02] Undoubtedly, one of the necessary assumptions for the development of this sector is stimulating regulatory framework which practically carries out the ideas of the rule of law. [01] Despite the fact that the economic crisis nega- 
tively influenced the trends in the development of the construction sector, the number of economic entities in this sector hasn't reduced. For example, in 2009 , in the construction sector in Montenegro there were a total of 1589 economic entities, and by the end of 2011 there were 1854 companies that carried out activities in this sector [21]. The above mentioned fact tells us about significant potential with which Montenegro deals with when it is about this economic sector. On the other hand, directly or indirectly, the construction sector influences other economic activities.[14] Also, empirical evidence has confirmed that construction sector has significant influence on GDP, labour market, national competitiveness and overall economic development.[22]

After a few years of stagnation caused by the consequences of the economic crisis, construction activity in 2013 and 2014 records growth according to all indexes. Thus, total value of completed construction works during 2013 , according to the data of the Statistical Office amounted to 269.7 million euros and was $9.7 \%$ higher compared to the same period in 2012. The value of new contracts on buildings was 70.4 million euros, which is $116.7 \%$ more than in the same period of the previous year, and the value of the new contracts on other construction was 65.3 million, i.e. $97.3 \%$ more compared with 2012. The strategic document of the Government of Montenegro, Directions of Economy Improvement, precisely quotes that the basic directions of the development of this sector are improved spatial planning, high quality of the construction products (sustainability), competitiveness of the construction companies and encouraging entrepreneurship, foreign investments, integration of illegal objects in the sector of formal housing, higher standards of energy efficiency and increased exploitation of energy from renewable resources. In order to achieve the above mentioned objectives, it is necessary to create a good quality legal and institutional environment. Unfortunately, general consent of the creators of the economic policy and economic entities who do the business in the construction sector in Montenegro, is there is a significant space for improving regulatory framework in this area.

Research of the business environment shows that the Montenegrin economy is not satisfied with the work of state bodies in carrying out the regulatory reforms in the construction sector. For example, in the research of the Montenegro Employers Federation, "Five Killers of Business", it is clearly stated that $97 \%$ of interviewed businessmen think that the current regulatory framework does not encourage companies to expand their activities.[13] The Foreign Investors' Council in Montenegro has been pointing out certain flaws in the regulatory framework for years and they pay special attention to the issues which improve the development of the construction sector, primarily the problem of issuing building permits, property registration and the slowness of the state administration to service the needs of the companies who do the business in this sector. The common denominator is the fact that unstable regulatory framework in which new economic restrictions for companies have been introduced in a short period of time or increased deadlines during the application for obtaining various licenses negatively reflect on the competitiveness of the national economy. [07]

Macroeconomic projections for the period 20152017 in Montenegro are significantly based upon the necessity of further development of the construction industry. According to the estimations of the creators of the economic policy in Montenegro, the period 2015-2017 will record faster growth of Montenegrin economy due to the growth of the investment activities and hiring national potentials, primarily in the construction sector. $[06,07]$ The construction sector will experience the biggest growth under the influence of the announced investment boom and it will be around $16 \%$, and hiring domestic construction operatives will have a multiplicative effect on those branches which are connected to the functioning of this sector: trade, transport, financial and insurance services, small production services and other.[28] The aim of this paper is to point to the significance of the regulatory changes for the development of the construction sector in Montenegro. During the topic research and writing of the paper, the authors tried to identify the deficiencies in the regulatory framework and point out their negative effect on the competitiveness of the construction sector. Also, they noticed and emphasized the positive examples where the regulatory changes in the construction sector positively influenced the development of the total competitiveness of the economy of Montenegro and an improvement of its position on the competitiveness lists which are published by the renowned international organizations. While researching the influences of the regulatory changes on the development of the construction sector, the authors used statistical and normative methods, and they also carried out 
a range of detailed interviews with the interested parties - economic entities from the construction sector, representatives from the Government and local self-management, as well as the representatives of the Employers Federation. Apart from analyzing individual legal acts, they also used publicly available publications and research of the relevant subjects in Montenegro who dealt with this topic.

\section{METHODS}

Key challenges in the regulatory framework of the construction sector

During the analysis of the regulatory framework, it is necessary to point out the fact that the construction sector has to be regarded in the broader context as a component of the economy, thus the problems it faces in many fields are common for the total economy - not enough understanding of the legislator for the businessmen, different approach in equal situations, slow procedures of obtaining licenses, insufficiently efficient judiciary system etc. [28] On the other hand, the aim of this paper is to show to concrete flaws in the legal arrangement of the construction sector. Due to the complexity of the regulations which control this area, and since there is plenty of them, because the construction sector is directly or indirectly connected with numerous business activities, the authors identified those flaws that show as the most significant in the government documents, research of the business associations and expert analyses - the issue of obtaining building permits, property registration, system of public procurement. They also identified but haven't elaborated into the details other problems in this area such as flaws in the system of space planning and arrangement, communal installation of the building plots, tax environment, slowness of the administration etc.

In the Strategy of developing the construction sector in Montenegro by 2020, key challenges in the regulatory framework were presented in a comprehensive way, and strategic opinion that good quality legal and institutional framework are the foundation for the development of the construction sector in Montenegro. The following issues are identified as the key problems: issuing building permits, property registration and problems with regards to the real estate registry, the question of adopting and implementing the technical standards, regulatory improvement of the system for energy efficiency of the objects, efficient implementation of the system of public procurements and high-quality institutional support. [27]

After doing a detailed analysis of various documents in this area, we point to the following questions as key regulatory challenges for the development of the construction sector in the future period:

- Creating an efficient and legally secure system for issuing building permits. Undoubtedly, the issue of building permits is in the long run the biggest challenge and so far the results in this area are described in more details further in the text.

- Improving overall labour law regulation in construction sector. This includes working permits regulation, work protection regulation etc. [10]

- Improving the quality of the arrangement of the property registration. The issue of registering and recording the property is also important for the function of the total construction sector. Some steps forward were made in this area in the previous period, but further reforms are necessary. The most significant problems of the land system in Montenegro in the previous period are the following ones: insufficiently developed land registry, frequent phenomenon of misbalance in various records in this area that is managed by state bodies - state tax offices, local institutions for managing plots and constructions, state statistics, a lot of territory that is not covered with the cadastre records etc.

- Introducing and implementing the appropriate technical standards and European Union regulative Standardization in the construction sector became a prerequisite for running a successful business. That is why Montenegro started the procedure of introducing Eurocodes and it is necessary to bring a whole range of regulations with the obligatory implementation in the construction sector. The process of standardization is being implemented in the area of contracting, and that is why they also consider adopting FIDIC conditions of the contracts as an obligatory basis for contracting works in the system of public procurements.[18]

- Further improvement of the system of public procurements in the construction sector. Legislative changes since 2012 have significantly improved the total system of the public 
procurements in Montenegro.[09] Still, even apart from positive marks in the reform of the system of public procurements, experience in the implementation of this law, especially in the construction sector, points to certain flaws which have to be analyzed and removed so that this area can be improved. That is why we show the key drawbacks of the system of public procurements from the construction sector's point of view which influences the competitiveness of this sector, but also the total competitiveness of the national economy. These are: activities of the institutions which carry out the system of public procurements, interpreting the regulations by the entities that implement the law, disrespecting basic principles of public procurements by the offerors in practice, activities of the committees for opening and validating the offers, slowness and long duration of the procedure of public procurement etc.[20]

- The necessity of mutual coordination of legislature and improving the institutional capacity for realizing constructing of projects. Numerous researches of the business environment, but also official government analyses show that a particular problem for realizing investment projects in the past decades represent the slowness of the state administration and long terms for obtaining various documents and consent for building. There is also a problem of who is in charge for issuing various conditions and consents determined by not only one law, but by other regulations concerning the environment protection etc. Existing different requests which are posed for the investors, and which are not concentrated in one document, additionally makes the investors' job even more difficult. On the other hand, the slowness of the administration and insufficient awareness of the significance of investments represent a special problem which needs long term attention because it can't be solved exclusively by bringing rules, but by gradual implementation of the total environment in which the state government functions.

- Improving the system of spatial planning. One of the most important strategic documents of the Government of Montenegro, Spatial plan of Montenegro by 2020, points to numerous problems in spatial planning whose long term high-quality solving would create assump- tions for improving the construction sector. The following problems are emphasized as the most significant ones in this document: inter-sectoral mismatch of the laws that regulate this area, not precisely defined relationships between developmental and normative content of the spatial-planned and urban planning documents, frequent and lengthy changes of municipal spatial plans and general urban plans, insufficient monitoring over the plan implementation and inefficient activities of the inspection services.[25] When The Law on Spatial Planning and building objects was brought in 2008, The laws that specially regulated certain segments were out of force. These were: The Law on Spatial Planning and Development ("Off. Gazette of Republic of Montenegro", 28/05), the Law on Plots ("Off. Gazette of Montenegro", 55/00) Law on Constructing objects ("Off. Gazette of Montenegro", 55/00, 40/08, 34/11) and the Law on Urban and Construction inspection ("Off. Gazette of Montenegro", 56/92). This law comprised four areas which used to be defined by separate laws (spatial planning and development, constructing objects, plots and inspection monitoring over the planning and constructing), which represents a rationalization for sure. One of the main objections of the investors concerns the fact that certain issues regarding building objects is treated by a range of other laws and bylaws which are partially mismatched in the parts with regards to building objects, whereas some objections were incomplete and not in compliance with the Law on spatial planning and building objects.[26, 07]

We emphasize the efforts on creating a stimulating tax environment as affirmative solutions in the previous period. For example, by adopting and implementing the Law on spatial planning and building objects from 2009, a fee for using city plots was cancelled and they gave numerous benefits to the investors during the calculation of the fees for communal equipment. Also, according to the new Amendments to the Law on Property Tax which will be implemented from 01.01. 2016, one of the most significant novelty anticipates introducing exemption from paying the taxes on the objects and special parts of the residential buildings owned by the investors which are shown in the journals as investments in progress or stocks of the finished products and which are intended 
for further sale. Above mentioned solutions will represent a significant stimulus for further building and development of the construction sector.

Evaluating the reforms in the construction sector through positions in doing business report

Flanagana et. al summarize the latest developments in competitiveness in construction sector.[05] Competitiveness is a multidimensional phenomenon - indispensably present at the level of firms, sectors, and the country as a whole.[16] Over the time, the concept of competitiveness has undergone significant changes.[17] Construction sector competitiveness has been a subject of interest for many years. [04] Namely, quality of construction sector is one among key elements which determinates the overall nation competitiveness.[08] The competitiveness indexes of the most prestigious international institutions (World Economic Forum, World Bank, Heritage Foundation, etc.), that empirically measure the competitiveness of the national economy, in a number of elements assess the legal and institutional aspects of construction sector.

The index of easiness of doing business represents one of the most frequently used indexes concerning the evaluation of the environment of doing business of a company. High ranked index of easiness of doing business represents an important parameter for the future investors during bringing decisions on investing the capital in a country or a particular economic sector in the country. Also, the results of Doing business report are important because they talk about what the public management can do in a short period of time so that it can contribute to the easier business activities. Starting assumption of the research is that the private sector is the bearer of the economic growth, and in order that the private sector can develop, it is necessary that administrative hurdles and limitations would be reduced to the minimum so that they can Maximize the facilitation of the interaction between economy and administration, but that there is also a legislative and judiciary system which guarantees realizing rights in practice.[11] Due to the above mentioned arguments, we thought that it is necessary to monitor the position of Montenegro in this report and to compare the improvement which has been made in the recent years concerning the areas from this report that directly affect this sector.

It is necessary to point out the fact that certain problems connected with regulatory framework in the construction sector were the cause of the bad position of Montenegro on this list in previous years. These are - obtaining the building permit and the issue of property registration. Officially, according to the reports for years 2014 and 2015, Montenegro has significantly reformed and improved the areas of issuing building permits and property registration. The information that the biggest 10 countries reformers in this area in 2014 tells us about the significance of reforming. Also, in 2014 , the area in which most regulatory reforms were carried out is "issuing building permits", and exactly 9 out of 10 countries reformers implemented the reforms.[30]

Obtaining building permits is one of the key challenges for companies that do business in the construction sector in Montenegro. Based upon the report "Doing Business" of the World Bank from 2013, Montenegro was on a very low position 176 out of 185 countries (Table 1 ).

Table 1: Doing Business Report

\begin{tabular}{|l|c|c|c|c|c||}
\hline Doing Business Report & 2015 & 2014 & 2013 & 2012 & $\begin{array}{c}\text { Change compared } \\
\text { with 2012 }\end{array}$ \\
\hline Starting the business & 56 & 48 & 58 & 47 & -9 \\
\hline $\begin{array}{l}\text { Obtaining building } \\
\text { permits }\end{array}$ & 138 & 465 & 176 & 173 & 35 \\
\hline Property registration & 87 & 87 & 117 & 108 & 21 \\
\hline Protecting investors & 43 & 43 & 32 & 29 & -14 \\
\hline Taxes & 98 & 97 & 81 & 108 & -10 \\
\hline Respecting the contract & 136 & 136 & 135 & 133 & -3 \\
\hline Closing the business & 33 & 31 & 44 & 52 & 19 \\
\hline
\end{tabular}


Such a bad position of Montenegro was a consequence of long, complex and insufficiently transparent and expensive procedures of obtaining building permits. Also, according to the perception of the interviewed businessmen, this area is the one which was connected with corruption. For example, the results of one research of the Montenegro Employers Federation on the quality of the business environment in Montenegro showed that $21 \%$ of the interviewees see the procedure of obtaining the building permit as an area where bribing and corruption were most expressed [12].

\section{RESULTS AND DISCUSSION}

The process of obtaining building permits in Montenegro is still very complex, although significant simplifications were done and two procedures which still present a big problem to the investors are determined. These are Urban-technical conditions (45 days) and building permits (60 days). During the carrying out of the reform which aimed to facilitate the realization of the business operations and bigger inflow of the foreign capital in the reform from 2008, the following procedures were terminated: solution on location, solution on appointing the performer of the Main project revision, solution on approving preparation works, solution on urban consent. Since the reforms that were carried out in 2009 showed as very effective and beneficial, the following reforms were terminated in 2010: approval for carrying out geological researches (for all objects), consent to the elaborate on geological research, consent on electric power, sanitary consent, and agricultural consent. In the Doing Business report for 2013 they recognized the efforts of the Government of Montenegro to reduce time, financial and procedural overload of the investors during issuing building permits. Although this area experienced significant reforms, it is still necessary to point out that the efforts were not good enough for improving the position primarily due to the fact that collecting documentation and total procedure was carried out by investors themselves. Apart from that, although the law defined and simplified the regulations, according to the report - it is stated that this procedure still lasts for too long in practice. Still, in Doing Business report from 2014 in the area of issuing building permits, a step forward was made for 11 places (see the Table 1). The biggest novelty in this area is introducing the principle of one window (one stop shop) where one can obtain all necessary consents for the per- mit at one place. Significantly improved position in this criterion is a result of reduced number of procedures for obtaining the permit from 16 to 9 , as well as reduced terms of delivery which shortens the procedure from 267 to 158 days compared with the Report for the year 2013. On the other hand and, with regards to costs, Montenegro was still on the top with the biggest costs which amount more than 60,000 Euros on the Doing Business model. The biggest amounts in costs are high fees for communal equipment of the plot, which amount around 45,000 Euros in this case on the example of the Capital City Podgorica which was comprised by the Report. Still, in the Doing Business report for 2015, the position has improved a lot because it recorded reduced duration of the procedure, but the lower costs paid by the investor as well.[19] Viewed for the period 2012-2015, Montenegro improved its position 35 places with regards to the criterion of issuing building permits. In the area of property registration, an improvement of 21 places in the period 2012-2015 was recorded, primarily due to simplified property registration by introducing a notary system. Better position is a result of reduced number of procedures for obtaining the solution on real estate registration in the cadastre from 7 to 6 days, while the terms and costs remained the same. According to the data of the index of easiness of doing business for the year 2013, Montenegro took the 51st place, which represents a fall of four places compared with the previous year.[29] In the report for 2014 year, it took the 44th place, which represents a big step forward on the ranking list.[30] Finally, in the Report for the year 2015, Montenegro significantly improved its position and took the 36th place.[31] The biggest changes which led to improving the position on the ranking list derive from the reforms on areas of obtaining building permits and property registration. $[03,15]$

\section{CONCLUSION}

The construction sector as an economic activity is directly or indirectly connected with a big number of regulations of various legal power and content. Out of total number of real estate and its registration, spatial planning, issuing building permits, tax environment, over the carrying out of the contract on economic-legal activities, the common denominator of the regulative is the need that it should be predictable, mutually adjusted and applicable on the business entities that it refers to. 
The research of the influences of the regulatory changes on the development of the construction sector imposes itself as one of the basic conclusions that the efficient transformation of regulation, primarily in the area of building objects and property legal relations is a precondition for improving this sector. Also, the whole legal system which affirms the idea of the rule of law is a necessary prerequisite for developing the construction sector. We noticed and clearly pointed out certain problems in the legal framework which we consider they negatively influenced the improvement of the competitiveness of this sector and the national economy. As the most significant, the following ones are identified: trend of provisions instability, existence of mutual collision of laws and sublegal acts, regulation of spatial planning, registering property and system of public procurement. We particularly pointed out the fact that frequent absences of applying the adopted rules, the slowness of the administration and lack of awareness on the significance of investment, represent a long term problem which cannot be solved by bringing provisions, but by transforming total state management into the public service of citizens and economy. Finally, a common conclusion is imposed that the results up till now, especially reforms that were carried out after the economic crisis in the construction sector show that Montenegro seriously approaches this issue, and the best evidence for this attitude is the improving the position of Montenegro on the competitiveness lists of relevant international organizations.

\section{REFERENCES}

1) Bevan, A., Estrin, S. and Mayer, K. (2003). Foreign investment location and institutional development in transition economies, International Business Review 13, pp. 43-64. Available at: http://www.klausmeyer.co.uk/publications/2004_bevan_meyer_estrin_IBR.pdf.

2) Ćetković J. et. al. "Primary directions and advancements in competitiveness of Montenegrin construction sector", Procedia Engineering, ISSN: 1877-7058, Vol. 117, 2015. pp. $780-790$.

3) Ćetković, J., Knežević, M., Žarković, M., Murgul, V., Vatin, N. (2014), Development and competitiveness improvement of the construction sector in Montenegro Applied Mechanics and Materials, Vols. 638-640, pp. 2465-2470.
4) Dangerfield B., Green S., Austin S., (2010) Understanding construction competitiveness: the contribution of system dynamics, Construction Innovation, Vol. 10 Issue: 4, pp. $408-420$.

5) Flanagana R., Lua W., Shenb L., Jewella C., (2007), Competitiveness in construction: a critical review of research, Construction Management and Economics, Volume 25, Issue 9, pp. 989-1000.

6) Foreign Investors' Council in Montenegro. (2013). White pages 2013: view ahead, pp. 15. Retrieved from website: www.mfic.me/ files/BijelaKnjiga.pdf.

7) Foreign Investors' Council in Montenegro. (2013). White pages 2013: view ahead, pp. 46-47. Retrieved from website: www.mfic. me/files/BijelaKnjiga.pdf.

8) Huggins R., Izushi H., (2015), The Competitive Advantage of Nations: origins and journey, Competitiveness Review, Vol. 25 Issue: 5, pp. $458-470$.

9) Jocovic M., (2013), Current problems in implementation of the Law on public procurements in Montenegro, Law and economy - journal for legal-economic theory and practice, no. 7-9, pp. 514 - 525.

10)Lawrencea R., Paredes Gilb M., Flückigerc Y., Lambertb C., Wernad E., (2008) Promoting decent work in the construction sector: the role of local authorities, Habitat International, Volume 32, Issue 2, pp. 160-171.

11)Milovic N., (2012), Common market and policy of competitiveness of the European Union, The University of Montenegro - The Faculty of Economics, pp. 210-211.

12) Montenegro Employers Federation, Creating the environment for sustainable development of companies in Montenegro, pp. 21.

13)Montenegro Employers Federation. (2012). Five killers of business, pp. 5-6. Retrieved from: www.poslodavci.org.

14)Polenske K., Sivitanides P. (1990), Linkages in the Construction Sector, The Annals of Regional Science, 24 (2): 147-161.

15)Popović, S., Djurovic, N., Murgul, V. (2015), Formation, Development and Issues of Montenegro Rural Settlements in the Case of Village Orja Luka in Bjelopavlici Procedia Engineering, Vol. 117, pp. 832-840. 
16)Porter , M. (1990), "The competitive advantage of nations", New York: Free Press.

17) Porter, M., Delgado, M., Ketels, K., Stern, S. (2012), "The determinants of national competitiveness", National Bureau for Economic Development, NBER Working Paper No. 18249.

18)Rutešić S., et. al., (2015), Analysis of the Situation in Montenegrin Civil Engineering Sector from the Point of Application of National Regulations and the EU Technical Standards in Construction, Procedia Engineering, ISSN: 1877-7058, Vol. 117, pp. 905 - 915.

19) See for more details: http://www.doingbusiness.org/data/exploreeconomies/ montenegro\#dealing-with-construction-permits.

20)See for more details: Melovic B., Jocovic M., (2013), Public procurement as a determinant of competitiveness of the construction sector in Montenegro", Nehnutelnosti a bývanie, Slovak University of Tehnology in Bratislava, 5, ISSN: 1336-944X, pp. 94-101.

21) Statistical Office of Montenegro, Statistical Yearbook 2011, Podgorica, 2011, pp. 137-146.

22)Tan W., Construction and Economic Development in Selected LDCs: Past, Present and Future. Construction Management and Economics, 20(7), pp. 593-99.

23) The Government of Montenegro - Agency for promoting foreign investments, Strategy of attracting foreign direct investments 2013-15, Podgorica 2013, pp. 15-22. Available at: www.gov.me/.../FileDownload. aspx?rld=126665...2.
24)The Government of Montenegro, Directions of the economy development 20132016, Podgorica 2013, pp. 60-61. Available at: www.gov.me/.../FileDownload. aspx?rld=127804 ...2.

25)The Government of Montenegro, Spatial planning in Montenegro by 2020, (2008), Podgorica, pp. 28-29. Available at: http:// www.gov.me/files/1234791491.pdf.

26) The Government of Montenegro, Strategy of developing the construction sector in Montenegro by 2020, (2010), Podgorica, pp. 26-27. Available at: www.gov.me/files/1260782780.pdf.

27) The Government of Montenegro, Strategy of developing the construction sector in Montenegro by 2020, Podgorica, 2010, pp. 20-29. Available at: www.gov.me/files/1260782780. pdf.

28)Vasiljevic, M. (2011). Economy and rule of law Law and economy - journal for legal-economic theory and practice, 4 (6), pp. 17-43.

29)World Bank, Doing business 2013 - Smarter regulation for Small and Medium sized Enterprises. Available at: http://www.doingbusiness.org.

30)World Bank, Doing Business 2014 - Understanding Regulations for Small and MediumSize Enterprises. available at: http://www. doingbusiness.org.

31)World Bank, Doing Business 2015 - Going Beyond Efficiency, available at: http://www. doingbusiness.org.

Paper sent to revision: 23.12.2015.

Paper ready for publication: 03.03.2016. 
doi:10.5937/jaes14-9825

Broj rada: 14(2016)1, 352

\title{
NUŽNOST REGULATORNIH REFORMI KAO PRETPOSTAVKA DALJEG RAZVOJA GRAĐEVINSKOG SEKTORA U CRNOJ GORI
}

\author{
Mijat Jocović, Univerzitet Crne Gore, Ekonomski fakultet, Podgorica, Crna Gora \\ Nikola Milović, Univerzitet Crne Gore, Ekonomski fakultet, Podgorica, Crna Gora \\ Boban Melović, Univerzitet Crne Gore, Ekonomski fakultet, Podgorica, Crna Gora
}

U ovom radu autori su istraživali uticaj kvaliteta pravne regulative na razvoj sektora građevinarstva u Crnoj Gori. Autori su uočili i jasno istakli da značaj građevinarstva za ukupnu ekonomiju Crne Gore, njegov uticaj na ostale privredne djelatnosti i učešće $u$ društvenom bruto proizvodu države $u$ potpunosti opravdava potrebu za konstantnom pažnjom kreatora politike. U radu su uočeni i jasno istaknuti ključni problemi u pravnom okviru koji su negativno uticali na unapređenje konkurentnosti ovog sektora i nacionalne ekonomije. Kao najznačajniji identifikovani su: trend nestabilnosti propisa, postojanja međusobne kolizije zakona i podzakonskih akata, regulativa prostornog planiranja, izdavanje građevinskih dozvola, registracije imovine i sistem javnih nabavki. Nakon analize promjena u regulatornom okviru i njihovog uticaja na poboljšanje pozicije Crne Gore na listama konkurentnosti relevantnih međunarodnih organizacija, autori iznose opšti zaključak da su nužnost regulatorne reforme uz istovremeno obezbjeđenje predvidljivog i funkcionalnog sistema jedan od osnovnih preduslova za dalji razvoj ovog sektora.

Ključne reči: Građevinarsrtvo, Crna Gora, Regulatorne promjene, Građevinske dozvole, Registracija imovine 